\title{
CGNL1/CYP19A1 Fusion Gene
}

National Cancer Institute

\section{Source}

National Cancer Institute. CGNL1/CYP19A1 Fusion Gene. NCI Thesaurus. Code C99826.

A fusion gene that results from a chromosomal inversion within 15q21.2-q21.3 and places the promoter for the CGNL1 gene near the 5 ' end of the CYP19A1 gene. This fused gene causes increased expression of the CYP19A1 gene and is associated with aromatase excess syndrome. 